with hints for the improvement of those parts of it which are most injurious to health and morals," published in 1817 . In spite of the fact that Owen at this time has become less the great business man reformer and more the Utopian idealist and has begun his permanent break with the governing classes in his characteristically hopeful manner he dedicates his comments "most respectfully to the British Legislature."

It is Owen's idea that the new industrial system has been generating a new character in his inhabitants. The governing principle is "immediate pecuniary gain" which has permeated the lowest classes, and expresses itself there in its most harmful manner exploitation of children. In 1817 he pleads for a parliamentary act doing three things: I. "limiting the regular hours of labour in mills of machinery to 12 per day, including one hour and a half for meals"; 2. "children cannot be employed in factories until they are Io years old and shall not be employed more than 6 hours a day until they are I2"; 3 . children cannot work in factories "until they can read and write in an useful manner, understand the first four rules of arithmetic, and the girls be likewise competent to sew their common garments of clothing."

Owen is blissfully confident that all advance lies in training since "children may be taught any habits and any sentiments." Neglect of humanity as exemplified in the early nineteenth century spelled ruin, while education to Owen meant a Utopian progress not even practically conceived of because of a concept's inherent limitations.

\title{
The Famous Dictionary of the Eighteenth Century
}

The volumes are ponderous. The title-page in sonorous and dignified language informs one that this is "A Dictionary of the English Language in which the Words are deduced from their OrIGINALs, and illustrated in their different significations by examples from the best writers, to which are prefixed, a history of the language, and an English grammar. By Samuel Johnson, A.M. In Two Volumes." The page is then topped off in good Johnsonian style with a nineline Latin quotation from Horace.

The dictionary published in 1755 was formerly in the library of Benjamin Thomas Hill of Worcester, Mass. It was presented to the 
Business Historical Society through the kindness of friends of $\mathrm{Mr}$. Hill and members of the Society resident in Worcester. On the inside of the cover there is a copy (made about 1832) of Samuel Johnson's letter to Lord Chesterfield. Chesterfield, it will be recalled, repulsed Johnson, the struggling, eccentric hack writer, and courted the author in fame. The book went to press without a dedication. Johnson's sturdy independence speaks out in his letter dated Feb. ruary 7, I 755 to the Earl: "The notice which you have been pleased to take of my labours, had it been early, had been kind; but it has been delayed till I am indifferent, and cannot enjoy it; till $\mathrm{I}$ am solitary, and cannot impart it; till I am known, and do not want it."

Paging the volumes, one finds the definitions endlessly entertaining. Business means "employment; multiplicity of affairs" and for further elucidation Johnson quotes the lines of Donne:

Must business thee from hence remove?

$\mathrm{Oh}$ ! that's the worst disease of love.

It may also mean "an affair." In this sense it has the plural. And quoting from King Lear:
Bestow
Your needful counsel to our businesses,
Which crave the instant use.

Carriage is "the act of carrying or transporting, or bearing any thing." And Johnson takes from Bacon's Natural History, "The unequal agitation of the winds, though material to the carriage of sounds farther or less way, yet do not confound the articulation."

Of goose Johnson says, "A large waterfowl proverbially noted, I know not why, for foolishness." And for verification Johnson quotes:

From Macbeth:

Thou cream-faced lown,

Where got'st thou that goose look?

From King Lear:

Smile you my speeches, as I were a fool?

Goose, if I had you upon Sarum plain,

I'd drive ye cackling home to Comelot.

One of the most slippery words to the modern compiler is factory but to Sam Johnson in the middle of the eighteenth century two sentences sufficed: "I. A house or district inhabited by traders in a distant country. 2. The traders embodied in one place." 
As members of the Business Historical Society we turn to see what Johnson has said of history. He has three definitions:

I. A narration of events and facts delivered with dignity.

Justly Caesar scorns the poet's lays;

It is to history he trusts for praise. Pope.

2. Narration; relation.

What histories of toil could I declare?

But still long-weary'd nature wants repair.

3. The knowledge of facts and events.

Pope's Odyssey.

History, so far as it relates to the affairs of the Bible, is necessary to divines. Watt's Improvement of the Mind.

With Chesterfield in mind one looks up the word patron. Old Johnson never minced his phrases. His definition of a patron is, "One who countenances, supports or protects. Commonly a wretch who supports with indolence, and is paid with flattery."

\section{In fflemoriam}

As THE Bulletin goes to press we are informed of the sudden death of Charles F. Bacon, president of Chandler \& Co., Boston.

$\mathrm{Mr}$. Bacon's outstanding characteristic was his versatility. He was not only a veteran merchandiser but an Oriental rug expert, a lawyer, an ardent golfer, and a public-spirited citizen. His interest in activities for the social good covered his long life. He was in deep sympathy with the aim of the Business Historical Society to preserve the essential records of business history, and became a member of the organization in 1927 .

The Society regrets the loss of one of its greatest friends.

\section{Secretary's Column}

\section{ACQUisitions}

The Society gratefully acknowledges the receipt of the following aquisitions received since the last publication of the Bulletin:

From A. P. Taylor, Librarian, Archives of Hawaii, Honolulu.

The Hawaiian Islands: 